\title{
EVALUASI PENGENDALIAN BIAYA PRODUKSI GUNA MENINGKATKAN EFISIENSI BIAYA PRODUKSI PADA CV. CITRA SARI MAKASSAR
}

\author{
Andi Arifwangsa $A^{1}$, Faidul Adzim² ${ }^{2}$ Andi Ummi Alifah ${ }^{3}$ \\ Universitas Muhammadiyah Makassar \\ e-mail :d3pajak@unismuh.ac.id
}

\begin{abstract}
Research aims to know the evaluation of production cost control to increase the efficiency of production costs in $C V$. Citra Sari Makassar. This research uses the method of analysis of variance where the company data about the production process and other data that support the research is collected then the data is done analysis by describing and Compare with the data collected, and do the calculation process by comparing between the standard cost and actual cost. This research Data is derived from a direct interview with related parties, documentation, library review, and access to the Web and related sites. The research object is $C V$. Citra Sari Makassar. The results showed that there was control of production costs by comparing between standard cost and actual cost on $C V$. Citra Sari Makassar can reach a target of more efficient production cost.
\end{abstract}

Keywords: Control of production costs, production costs, efficiency of production costs

\begin{abstract}
Abstrak
Penelitian ini bertujuan untuk mengetahui evaluasi pengendalian biaya produksi guna meningkatkan efisiensi biaya produksi pada CV. Citra Sari Makassar. Penelitian ini menggunakan metode analisis varians dimana datadata perusahaan mengenai proses produksi serta data-data lain yang mendukung penelitian dikumpulkan kemudian data-data tersebut dilakukan analisis dengan cara mendeskripsikan dan membandingkan dengan data yang dikumpulkan, dan melakukan proses perhitungan dengan membandingkan antara standar cost dan actual cost. Data penelitian ini diperoleh dari wawancara langsung dengan pihak terkait, dokumentasi, tinjauan kepustakaan, dan mengakses web dan situs-situs terkait. Objek penelitian adalah CV. Citra Sari Makassar. Hasil penelitian menunjukkan bahwa adanya pengendalian biaya produksi dengan membandingkan antara standar cost dan actual cost pada CV. Citra Sari Makassar dapat mencapai target biaya produksi yang lebih efisien.
\end{abstract}

Kata kunci: Pengendalian Biaya Produksi, Biaya Produksi, Efisiensi Biaya Produksi 


\section{PENDAhuluan}

Era globalisasi menuntut segala aspek kehidupan seluruh masyarakat untuk berubah, lebih berkembang dan maju. Salah satu mekanisme yang yang menjadi ciri globalisasi dewasa ini adalah tekanan perdagangan yang kompetitif sehingga menuntut setiap perusahaan untuk meningkatkan keunggulan kompetitif mereka agar dapat memenangkan persaingan yang terjadi. Persaingan industri di era global saat ini meningkat sangat pesat. Persaingan ini timbul sebagai salah satu konsekuensi kemajuan ilmu pengetahuan dan teknologi. Persaingan ini menuntut sebuah industri terus mengembangkan kapabilitasnya demi memenuhi tuntutan dari pasar yang ada.

Dinamika dunia usaha yang begitu kompleks menuntut setiap perusahaan untuk tanggap terhadap setiap pergeseran serta perubahan yang terjadi pada lingkungan dunia usaha yang penuh dengan ketidakpastian. Ketidakpastian dan ketidak mampuan mengikuti perubahan akan menjadi awal dari kemunduran dan kelumpuhan bagi perusahaan. Oleh karena itu dalam rangka mempertahankan eksistensi dan kontinuitas usahanya, maka perusahaan dituntut kesiapannya dalam membuat konsep dan menyusun strategi kebijakan yang berorientasi pada perubahan. Untuk mempertahankan kelangsungan hidupnya, suatu perusahaan harus dapat mencapai tujuannya yaitu memperoleh laba maksimum. Biaya yang dikeluarkan oleh perusahaan harus benar-benar biaya yang memberi nilai tambah bagi produk sehingga tidak akan ada pemborosan biaya. Oleh karena itu, efisiensi biaya mempunyai arti penting bagi perusahaan dalam mempertahankan keberadaannya di dunia bisnis, juga dalam upaya menghadapi persaingan global yang semakin tajam.

Kartika, dkk (2012), tentang Evaluasi Pengendalian Biaya Produksi Guna Meningkatkan Efisiensi Biaya Produksi dengan Hasil Penelitian yaitu Persaingan di dunia bisnis yang ketat menutut setiap perusahaan yang bergerak di bidang industri, perdagangan maupun jasa harus dapat menjaga kelangsungan hidup perusahaan. Pada perusahaan manufaktur kelangsungan hidup perusahaan tergantung pada kegiatan utama perusahaan yaitu mengolah bahan baku atau bahan mentah menjadi barang jadi.

\section{TINJUAN PUSTAKA}

\section{Pengendalian Biaya Produksi}

Pengendalian produksi adalah berbagai kegiatan dan metode yang digunakan oleh manajemen perusahaan untuk mengelolah, mengatur, mengkoordinir, dan mengarahkan proses produksi (peralatan, bahan baku, mesin, tenaga kerja) ke dalam suatu arus aliran yang memberikan hasil dengan jumlah biaya yang seminimal mungkin dan waktu yang secepat mungkin. Pengendalian biaya yang efektif bergantung pada pengumpulan data serta penggalian laporan yang relevan (Arens dan Loebbecke, 2004). Pengendalian biaya dimulai dengan melakukan pencatatan-pencatatan semua transaksi yang dilakukan oleh perusahaan. Pengendalian dilakukan untuk memastikan bahwa pelaksanaan yang dicapai sesuai dengan tujuan dan rencana yang ditetapkan sebelumnya.

\section{Konsep Biaya}

Ony Widilestariningtyas, dkk (2012): Biaya sebagai nilai tukar, pengeluaran, pengorbanan untuk memperoleh manfaat. Beban dapat didefinisikan sebagai aliran keluar terukur dari barang atau jasa, yang kemudian ditandingkan dengan pendapatan untuk menentukan laba atau sebagai, "Penurunan dalam aktiva bersih sebagai akibat dari penggunaan jasa ekonomis dalam menciptakan pendapatan atau pengenaan pajak oleh badan pemerintah. Beban dalam arti luas termasuk semua biaya yang sudah habis masa berlakunya yang dapat dikurangkan dari pendapatan".

\section{METODE}

Pendekatan yang digunakan dalam penelitian ini adalah pendekatan kuantitatif dengan ilmiah yaitu berfikit untuk memecahkan masalah secara sistematis, empiris, dan terkontrol yang dengan angka-angka. Objek Penelitian ini adalah Lokasi penelitian ini dilaksanakan pada CV Citra Sari Kota Makassar yang beralamat Jl. Mannuruki II No. 69-B, Makassar Sedangkan waktu penelitiannya dilakukan kurang lebih 2 (dua) bulan pada tahun 2017. Adapun jenis data yang digunakan dalam penelitian ini adalah data kualitatif dan kuantitatof, sedangkan Sumber data yang diperoleh dalam penelitian ini adalah sumber sekunder yaitu berupa informasi tertulis lainnya yang berhubungan dengan penelitian. 


\section{Metode Analisis Data}

Metode analisis data yang dilakukan dalam penelitian ini untuk mengetahui tingkat efektifitas dan efisiensi biaya pabrik markisa CV. Citra Sari maka digunakan metode analisis varians. Analisis varians sebagai berikut:

Menurut Halim (2010), analisis varians merupakan proses menganalisa selisih biaya yang timbul karena perbedaan biaya yang sesungguhnya terjadi dibandingkan dengan biaya standar dan sebagaimana dikemukakan oleh LPPM (lembaga Pendidikan Pengembangan Manajemen) Akuntansi Manajemen

Jakarta, analisis varians bahan langsung, analisis varians upah langsung dan analisis varians biaya overhead pabrik.

Analisis Varians Bahan Langsung terbagi 2:

a. Varians Kuatitas

(Kuantitas standar - Kuantitas realisasi) x Harga standar

b. Varians Harga

(Harga standar - Harga realisasi) x Kuantitas realisasi Analisis Varians Upah Langsung terbagi 2:

c. Varians Efisiensi

(Jam standar - Jam realisasi) x Tarif standar

d. Varians Tarif

(Tarif standar - Tarif realisasi) x Jam realisasi Analisis Varians Biaya Overhead Pabrik terbagi 3:

e. Varians Pengeluaran

BOPTA + (JKS x TBOPVA $)-$ BOPS

f. Varians Kapasitas

(JKS x TBOPA) - BOPTA + (JKS x TBOPVA)

g. Varians Efisiensi

(JKA - JKS) x (TBOPA)

\section{HASIL DAN PEMBAHASAN}

\section{Hasil Penelitian}

a. Analisis Varians (selisih) Biaya Produksi Untuk tujuan pengendalian biaya produksi, analisis terhadap varians yang terjadi tidak hanya cukup dengan membandingkan anggaran dan realisasinya saja, apakah merugikan atau menguntgungkan. Akan tetapi varians yang terjadi juga perlu dianalisis lebih lanjut untuk mengetahui apakah varians yang terjadi disebabkan oleh perubahan efisien dalam proses produksi atau perubahan harga bahan atau tarif upah tenaga kerja langsung. Penyebab varians yang terjadi pada biaya bahan baku, biaya tenaga kerja langsung dan biaya overhead pabrik, diketahui dengan menggunakan analisis varians berdasarkan laporan penggunaan bahan baku dan laporan kegiatan produksi yang dilakukan oleh Manajemen CV. Citra Sari Makassar.

b. Analisis selisih (varians) biaya bahan baku langsung

Menurut Halim (2010), analisis selisih biaya bahan baku merupakan selisih yang disebabkan oleh adanya perbedaan antara biaya bahan baku sesungguhnya terjadi dengan biaya bahan baku standar dan selisih ini disebabkan oleh adanya perbedaan harga sesungguhnya dengan harga standar. Analisis varians biaya bahan baku CV. Citra Sari Makassar terdiri dari analisis varians harga bahan baku dan analisis varians pemakaian bahan baku. Adapun analisis tersebut akan diuraikan sebagai berikut:

Selisih biaya bahan baku, dimana:

$$
\begin{aligned}
& \text { Harga standar (HSt) = Rp. } 63.300 \\
& \text { Harga sesungguhnya (HS) = Rp. } 54.300 \\
& \text { Kuantitas standar }(\mathrm{KSt})=38.173 \mathrm{~kg} \\
& \text { Kuantitas sesungguhnya (KS) }=35.173 \mathrm{~kg} \\
& \text { (HSt - HS) x KS (63.300 - 54.300) x } 38.173 \\
& =9.000 \times 38.173 \mathrm{~kg} \\
& =\text { Rp. 2.072.730.600 }
\end{aligned}
$$

Selisih kuantitas biaya bahan baku

$$
(\mathrm{KSt}-\mathrm{KS}) \text { x HS }
$$

$$
\begin{aligned}
(38.173-35.173) \times 63.300 \\
=3.000 \times \text { Rp. } 63.300 \\
=\text { Rp. } 2.226 .412 .727
\end{aligned}
$$

Total selisih biaya bahan baku

$$
=\text { Rp. 4.299.143.327 }
$$

Tabel 1. Rekapitulasi Varians Biaya Bahan Baku CV. Citra Sari Makassar Tahun 2016

\begin{tabular}{lccc}
\hline \multirow{2}{*}{ Biaya Bahan Baku } & Selisih (varians) & \multicolumn{2}{c}{ Keterangan } \\
\cline { 3 - 4 } & $(\mathrm{Rp})$ & Unfavorable & Favorable \\
\hline Selisih harga bahan baku & 2.072 .730 .600 & & $\checkmark$ \\
\hline Selisih kuantitas bahan baku & 2.226 .412 .727 & $\checkmark$ \\
\hline Jumlah & 4.299 .143 .327 & & $\checkmark$ \\
\hline
\end{tabular}

Sumber: CV. Citra Sari Makassar (data diolah 2017) 
Tabel 1 menunjukan selisih (varians) biaya bahan baku pada CV. Citra Sari Makassar pada tahun 2016 adalah sebesar Rp. 4.299.143.327 yang terdiri dari selisih harga bahan baku Rp. 2.072.730.600 dan selisih kuantitas bahan baku yaitu Rp. 2.226.412.727 merupakan selisih yang menguntungkan (favorable).

c. Analisis selisih (varians) biaya tenaga kerja langsung

Selisih biaya tenaga kerja langsung adalah perbedaan antara biaya tenaga kerja langsung sebenarnya dengan biaya tenaga kerja standar. Selisih biaya tenaga kerja langsung terdiri dari dua macam selisih, yaitu selisih jam tenaga kerja dan selisih upah tenaga kerja langsung. Perusahaan telah melakukan analisis selisih jam tenaga kerja langsung dan perusahaan memiliki jam standar kerja untuk menghasilkan produk dan perusahaan telah melakukan analisis selisih tarif upah. Analisis biaya tenaga kerja langsung yaitu:
Selisih (varians) biaya tenaga kerja langsung

Dimana:

Jam kerja standar $(\mathrm{JKSt})=400.000$

Jam kerja sesungguhnya $(\mathrm{JKS})=350.000$

Tarif upah standar (TUSt) $=300.000$

Tarif upah sesungguhnya (TUS) $=300.000$

Jadi selisih biaya tenaga kerja langsung yaitu:

Selisih tarif upah

$$
\begin{gathered}
(\text { TUSt }- \text { TUS }) \times \text { JKS } \\
(300.000-300.000) \times 350.000=\text { Rp. } 0
\end{gathered}
$$

Selisih efisiensi upah

$$
(\mathrm{JKSt}-\mathrm{JKS}) \mathrm{x} \text { TUSt }
$$

$(400.000-350.000) \times 300.000$

$$
=\text { Rp. } 15.000 .000 .000
$$

Total selisih biaya tenaga kerja langsung $=\mathrm{Rp}$. 15.000.000.000

Tabel 2. Rekapitulasi Varians Biaya Tenaga Kerja Langsung CV. Citra Sari Makassar Tahun 2016

\begin{tabular}{lccc}
\hline \multirow{2}{*}{ Biaya Tenaga Kerja Langsung } & Selisih (varians) & \multicolumn{2}{c}{ Keterangan } \\
\hline Selisih Jam Kerja & $(\mathrm{Rp})$ & Unfavorable & Favorable \\
\hline Selisih upah & 0 & $\checkmark$ & $\checkmark$ \\
\hline Jumlah & 15.000 .000 .000 & & $\checkmark$ \\
\hline Sumber: CV. Citra Sari Makassar (data diolah 2017) & 15.000 .000 .000 & $\checkmark$
\end{tabular}

Tabel 2 menunjukan bahwa varians biaya tenaga kerja langsung pada CV. Citra Sari biaya Makassar tahun 2016 adalah Rp. 15.000.000.000 hal ini merupakan selisih yang menguntungkan (favorable).

\section{c. Analisis selisih (varians) biaya overhead pabrik}

Metode perhitungan selisih biaya overhead pabrik yang ditetapkan oleh perusahaan adalah metode analisis dua selisih. Berdasarkan metode ini, besarnya selisih biaya overhead pabrik diketahui dengan cara membandingkan antara biaya overhead pabrik yang sesungguhnya terjadi dengan biaya overhead pabrik menurut standar. Analisis biaya overhead pabrik anggaran tarif BOP / jam pada CV. Citra Sari Makassar yaitu:

Tarif BOP anggaran/jam

$=$ jumlah BOP tetap dan variable Jam kerja standar

$=\underline{121.000 .000}=302.5 / \mathrm{jam}$ 400.000
Tarif BOP tetap/jam

$=$ jumlah BOP tetap Jam kerja standar $=\underline{36.500 .000}=91.25 / \mathrm{jam}$ 400.000

Tarif BOP variable/jam $=$ jumlah BOP tetap Jam kerja standar

$$
=\frac{84.500 .000}{400.000}=211.25 / \mathrm{jam}
$$

Keterangan:

BOP sesungguhnya $($ BOPS $)=115.550 .000$

BOP tetap (BOPTA) $=34.750 .000$

Jam kerja sesungguhnya $=350.000$

Total BOP variable $($ TBOPVA) $=211.25$

a. Selisih (varians) pengeluaran (SP)

BOPTA + (JKS x TBOPVA $)-$ BOPS

$34.750 .000+(350.000 \times 211.25)-$

115.550 .000

$=108.687 .500-115.550 .000$

$=-6.862 .500$ (unfavorable)

b. Selisih (varians) kapasitas (SK) 


$\begin{array}{ll}(\mathrm{JKS} \times \mathrm{TBOPA})-\text { BOPTA }+(\mathrm{JKS} \mathrm{x} & =121.000 .000-105.875 .000 \\ \text { TBOPVA }) & =15.125 .000(\text { favorable })\end{array}$

$(350.000 \times 302.5)-34.750 .000+(350.000 \mathrm{x}$

211.25)

$=105.875 .000-108.687 .500$

$=-2.812 .500$ (unfavorable)

c. Selisih (varians) efisiensi (SE)

d. (JKA - JKS $) \times($ TBOPA)

$(400.000-350.000) \times(302.5)$
Berdasarkan analisis varians pengeluaran, varians kapasitas dan varians efisiensi tersebut diatas, maka rekapitulasi varians BOP pada CV. Citra Sari Makassar tahun 2016 dapat dilihat pada tabel berikut ini:

Tabel 3. Rekapitulasi Varians Biaya Overhead Pabrik CV. Citra Sari Makassar Tahun 2016

\begin{tabular}{llcc}
\hline $\begin{array}{c}\text { Biaya Overhead } \\
\text { Pabrik }\end{array}$ & \multicolumn{2}{c}{ Selisih (varians) } & \multicolumn{2}{c}{ Keterangan } \\
\cline { 3 - 4 } Selisih pengeluaran(SP) & -6.862 .500 & Unfavor able & Favor able \\
\hline Selisih kapasitas (SK) & -2.812 .500 & $\checkmark$ & $\checkmark$ \\
\hline Selisih efisiensi(SE) & 15.125 .000 & & \\
\hline Jumlah & Rp. 5.450.000 & $\checkmark$ &
\end{tabular}

Tabel 3 menunjukan bahwa selisih biaya pada CV. Citra Sari Makassar tahun 2016 adalah sebesar Rp. 5.450.000. hal ini berarti selisih biaya overhead tersebut tidak menguntungkan (unfavorable) disebabkan karena biaya yang dianggarkan lebih kecil dari biaya yang terealisasi. Ketiga selisih biaya overhead pabrik dalam hal ini selisih pengeluaran, selisih kapasitas, dan selisih efisiensi merupakan tanggungj awab bagian produksi. Berdasarkan hasil analisa biaya produksi tersebut maka rekapitulasi varians anggaran dan realisasi biaya produksi pada CV. Citra Sari Makassar tahun 2016 dapat dilihat pada tabel berikut:

Tabel 4. Rekapitulasi Varians Anggaran dan Realisasi Biaya Produksi CV. Citra Sari Makassar Tahun 2016

\begin{tabular}{lll}
\hline Biaya produksi & Anggaran (Rp) & Realisasi (Rp) \\
\hline Biaya bahan baku & 2.416 .350 .900 & 1.909 .893 .900 \\
\hline Biaya tenaga kerja langsung & 480.000 .000 .000 & 420.000 .000 .000 \\
\hline Biaya overhead pabrik & 121.000 .000 & 115.550 .000 \\
\hline Jumlah & 482.537 .350 .900 & 422.025 .443 .900 \\
\hline Sumber: CV. Citra Sari Makassar (data diolah 2017)
\end{tabular}

Tabel 4 menunjukan Pada CV. Citra Sari Makassar telah menyusun anggaran dan realisasi biaya produksi yang terdiri dari biya bahan baku yang dianggarkan Rp. 2.416.350.900 dan terealisasi Rp. 1.909.893.900 sehingga dari hasil perhitungan dengan menggunakan analisis tidak terjadi selisih yang merugikan yaitu $\mathrm{Rp}$. 4.299.143.327. Pada biaya tenaga kerja langsung, biaya yang dianggarkan yaitu $\mathrm{Rp}$. 480.000 .000 .000 dan yang terealisasi yaitu $R p$. 420.000.000.000 terdapat selisih yang menguntungkan yaitu Rp. 15.000.000.000 dan pada biaya overhead pabrik yang dianggarkan yaitu Rp. 121.000.000 dan yang terealisasi $\mathrm{Rp}$. 115.550.000 terdapat selisih yang merugikan yaitu (Rp.5.450.000), jadi total biaya produksi Rp. 19.304.593.327 antara biaya bahan baku, biaya tenaga kerja langsung, biaya overhead pabrik tidak terjadi selisih yang merugikan.

\section{Efisiensi Biaya Produksi}

Menurut Mulayadi (1993), efesiensi biaya produksi merupakan suatu hal yang penting yang harus dilakukan oleh perusahaan untuk mencapai laba yang optimal. Perusahaan harus tepat dalam menetapkan harga yang harus dikeluarkan untuk biaya produksi supaya efisiensi biaya produksi dapat secara konsisten dapat diterapkan perusahaan. Hasil analisis varians Biaya produksi pada CV. Citra Sari Makassar yaitu sebagai berikut:

1. Biaya Bahan Baku

Hasil analisis biaya bahan baku pada CV. Citra Sari Makassar pada tahun 2016 adalah Rp. 4.299.143.327 yang terdiri dari selisih harga bahan baku Rp. 2.072.730.600 dan selisih kuantitas bahan baku sebesar Rp. 2.226.412.727. hal ini menujukan bahwa selisih 
bahan baku tersebut merupakan selisih yang menguntungkan (favorable), jadi tugas seorang manajemen dalam membuat anggaran biaya bahan baku telah efisien.

\section{Biaya Tenaga Kerja Langsung}

Hasil analisis biaya tenaga kerja langsung pada CV. Citra Sari Makassar tahun 2016 adalah Rp. 15.000.000.000 yang terdiri dari selisih tarif upah sebesar Rp. 15.000.000.000 dan selisih efiisiensi upah sebesar Rp.0. hal ini merupakan selisih yang menguntungkan (favorable) dikarenakan jam kerja yang distandarkan lebih tinggi dari yang teraktual, hal ini menunjukan bahwa tugas manajemen dalam membuat rencana anggaran biaya tenaga kerja telah efektif. 3. Biaya Overhead Pabrik.

3. Hasil analisis biaya overhead pabrik pada $\mathrm{CV}$.

Citra Sari Makassar pada tahun 2016 adalah Rp. $\quad-5.450 .000$ yang terdiri dari selisih pengeluaran Rp. 6.862.500, selisih kapasitas Rp. -2.812.500, dan selisih efisiensi Rp. 15.125.000. Hal ini menunjukan bahwa biaya overhead pabrik tersebut merupakan selisih yang merugikan (unfavorable). Hal ini disebabkan karena biaya yang dianggarkan lebih kecil dari realisasi. Ketiga selisih biaya overhead pabrik dalam hal ini selisih pengeluaran, selisih kapasitas, dan selisih efisiensi merupakan tanggungjawab bagian produksi, hal ini menunjukan bahwa tugas seorang manajemen dalam membuat anggaran belum efisien.

\section{Pembahasan}

Berdasarkan hasil analisis yang dilakukan penulis diperoleh hasil evaluasi pengendalian biaya produksi dapat diketahui tingkat efisiensi biaya setelah dibandingkan antara standar cost dan actual cost pada CV. Citra Sari Makassar yang artinya hipotesis diterima. Hal ini dikarenakan terdapat selisih yang menguntungkan (favorable) yaitu dari biaya produksi. Hipotesis yang diajukan telah terbukti yaitu dari total anggaran biaya produksi sebesar Rp. 482.537.350.900 dan yang terealisasi sebesar Rp. 422.025.443.900 sehingga terdapat selisih yang menguntungkan (favorable) sebesar Rp. 60.511.907.000.

Penelitian ini sejalan dengan penelitian yang telah dilakukan oleh Tri Istanto (2010) tentang evaluasi metode biaya standar dalam pengendalian suatu biaya produksi pada $\mathrm{CV}$. Rahma Abadi Boja, bahwa hasil analisis data yaitu peranan biaya standar ternyata sangat membantu sekali bagi manajemen dalam usaha meningkatkan efektivitas. Penetapan biaya standar (bulan Agustus) pada periode produksi bulan September mengalami efisiensi biaya pada biaya overhead pabrik meskipun terjadi selisih yang tidak menguntungkan pada biaya bahan baku, namun secara keseluruhan laba yang didapat lebih optimal dari periode produksi yang lalu. Oleh sebab itu sebaiknya biaya standar dalam meningkatkan efektivitas, pengendalian biaya produksi tetap diteruskan.

\section{KESIMPULAN DAN SARAN}

\section{Kesimpulan}

Penelitian ini mengambil judul evaluasi pengendalian biaya produksi guna meningkatkan efisiensi biaya produksi pada CV. Citra Sari Makassar. Tujuan dari penelitian ini adalah Apakah evaluasi pengendalian biaya produksi dapat diketahui tingkat efisiensi biaya produksi setelah dibandingkan antara standar cost dengan actual cost pada CV. Citra Sari Kota Makassar. Jadi kesimpulan dari uraian dan hasil penelitian yaitu:

a. Dari hasil selisih (varians) biaya produksi pada CV. Citra Sari Makassar ternyata menghasilkan selisih-selisih yang menguntungkan (favorable) antara biaya bahan baku, biaya tenaga kerja langsung, dan biaya overhead pabrik.

b. CV. Citra Sari Makassar pengendalian biaya produksi dengan membandingkan antara standar cost dan actual cost yang menggunakan metode analisis selisih (varians), maka hipotesis yang diajukan telah terbukti yaitu total anggaran biaya produksi sebesar Rp. Rp. 482.537.350.900 dan yang terealisasi sebesar Rp. 422.025.443.900 sehingga terdapat selisih yang menguntungkan yaitu Rp. 60.511.907.000 (favorable)

c. Dengan adanya pengendalian biaya produksi dengan membandingkan antara standar cost dan actual cost pada CV. Citra Sari Makassar dapat mencapai target biaya produksi yang lebih efisien dimana anggaran yang disediakan perusahaan lebih besar dari pada terealisasi

\section{Saran}

Berdasarkan hasil penelitian yang didapat, maka penulis memberikan saran-saran sebagai berikut : 
a. Dalam pengendalian biaya produksi guna meningkatkan efesiensi biaya produksi dengan metode analisis varians, perusahaan perlu melihat dan mengidentifikasi penyimpangan yang terdapat pada biaya produksi untuk meningkatkan penjualan.

b. Dengan adanya efisiensi biaya produksi, perusahaan harus memikirkan menggunakan biaya yang merupakan sselisih antara stndar cost dan actual cost untuk meningkatkan volume produksi, kemudian memperluas wilayah pemasarannya, sebab terdapat kelebihan biaya. Ini berarti pemborosan dalam menetapkan biaya produksi. Hal ini dapat memeprkecil laba prusahaan.

c. Untuk mendapatkan pengendalian biaya yang efektif dan efisien maka diharapkan perusahaan menggunakan anlisis (varians) metode dua selisih dan metode tiga selisih agar informasi biaya dan selisih-selisih yang terjadi lebih mudah diketahui bila terjadi halhal yang menyimpang terhadap penggunaan biaya produksi sebab bilamana salah alokasi biaya maka hal ini dapat menyebabkan terjadinya pemborosan, dan bilamana terjadi pemborosan akan memperkecil laba yang diinginkan.

\section{REFERENSI}

Ayunyngtias, Dwinta. 2013. Evaluasi Penerapan Biaya Standar Sebagai Alat Perencanaan dan Pengendalian Biaya Produksi Pada Harian Tribun Timur Manado Vol. 1 No. 4

Arens, Alvin A., L. Loebbecke. (2008). Auditing Pendekatan Terpadu, Terjemahan oleh Amir Abadi Yusuf, Buku Dua, Edisi Indonesia. Jakarta: Salemba Empat.

Dunia, Firdaus A., Wasilah Abdullah. 2009. Akuntansi Biaya Edisi 2. Jakarta: Salemba Empat.

Dewi, Sofia Prima. 2014. Akuntansi Biaya Edisi 2. Bogor: In Media

Hapsari, Stephani Dian., Bobby W. Saputra., Bambang Rismandi. 2015. Evaluasi Efektifitas Pengendalian Biaya Produksi dan Efisiensi Biaya Produksi Vol. 2 No.1

Hasibuan, David. 2010. Peranan Anggaran Biaya Produksi Sebagai Alat Pengendalian Dalam Kaitannya Dengan Realisasi Biaya Produksi Pada PT. Sigma Utama
Halim, Abdul. (2007). Akuntansi Keuangan Daerah. Jakarta: Salemba Empat.

Horngern, Charles. 2008. Akuntansi Biaya. Jakarta

Harahap, N., Vera, D. K. (2008). Pengaruh Efisiensi Biaya Produksi terhadap Laba Bersih. Jurnal Akuntansi FE USU

Istanto, Tri. (2010). Evaluasi Metode Biaya Standar Dalam Pengendalian Suatu Biaya Produksi. Untuk keberlangsungan proses produksi.

Kartika, Dina., Dwi Atmanto., M. G. Wi Endang. 2012.Evaluasi Pengendalian Biaya Produksi Guna Meningkatkan Biaya Produksi.

Munandar, M. 2001. Budgeting, Perencanaan Kerja Pengkordinasian Kerja Pengawasan Kerja. Edisi Pertama. BPFE Universitas Gajah Mada. Yogyakarta.

Mulyadi. 2010. Akuntansi Biaya. Universitas Gajah Mada. Yogyakarta

Putri, Vergiana Nurtias Hery. 2011. Efektifitas Anggaran Biaya Produksi Terhadap Pengendalian Biaya Produksi.

Pratama, Bayu Putra., Anjuman Zukhri., Luh Indrayani. 2014. Analisis Biaya Standar Sebagai Alat Pengendalian Biaya Produksi Pada UD Wikrama Nutrisindo Desa Padang Sambian Kaja, Denpasar Barat Vol. 4 No. 1

Pratiwi, Juvita. 2013. Penerapan Biaya Standar Dalam Pengendalian Biaya Produksi pada PT. Pertani (PERSERO) Vol. 1 No. 4

Rosidah, E., Krisnandi, C. (2008). Peran Anggaran Biaya Produksi dalam Menunjang Efektifitas Pengendalian Biaya Produksi. Jurnal Akuntansi FE Unsil.

Wijaya, Yuke Oktalina., Lili Syafitri. 2015. Analisis Pengendalian Biaya Produksi dan Pengaruhnya Terhadap Laba Pabrik Penggilingan (PP) Srikandi Palembang.

Widilestariningtyas, Ony., Sri Dewi Anggadini., Dony Waluya Firdaus. 2012. Akuntansi Biaya. Yogyakarta: Graha Ilmu

Halim. (2010:278). Akuntansi Biaya. Jakarta: Salemba Empat

Mulyadi (1993). Akuntansi Manajemen, Edisi 3. Yogyakarta: STIE 